\title{
The Integrated Prevention Model for Marijuana Smuggling in Land Border Region of Indonesia-Papua Nugini (Case: Muara Tami District, Jayapura City, Papua Province)*
}

\author{
Heny Batara Maya, ${ }^{1}$ Mohammad Kemal Dermawan, ${ }^{2}$ \\ Vinita Susanti ${ }^{3}$ \\ Criminology, Social and Political Sciences, University of Indonesia \\ 10.15408/jch.v8i3.18421
}

\begin{abstract}
This paper describes the need for an effective preventive model in preventing the smuggling of marijuana in the Indonesia-Papua New Guinea land border area in Muara Tami District, Jayapura Papua. The model applied so far is an outward-looking model where this model implements an integrated cross-border inspection, supervision, and security. The unstructured interview approach and the Delphi method were used in this study so that accurate data was obtained that in practice, the current model used still did not look professional and integrated, namely between cross-border service officers, Police and defense, Ondoaffi. Traditional leaders, religious leaders, and border communities in the Indonesia-Papua New Guinea region. Besides, the integration between Ministries/Institutions related to programs and budgets to prevent marijuana smuggling in the Indonesia-Papua New Guinea border area in Muara Tami District, Jayapura City, Papua Province is also still weak. The reason people who choose to smuggle marijuana is because they do not feel guilty and think that it is a profitable job with a strong social network, the behavior that neutralizes themselves that carrying marijuana is not a crime. Besides, the existence of problems such as geographic, demographic, and disturbance from armed crime groups (OPM) that have not received serious action are also factors related to the above problems. Based on this background, this dissertation provides a strategic step, contained several policy recommendations that can strengthen this model so that it is expected to be maximized and more efficient than the previous model.
\end{abstract}

Keywords: Land Border Territory, Organized Crime, Social Networking, Neutralization, and the Delphi Method, The Crime Prevention Model of Cannabis Smuggling

${ }^{*}$ Received: September 11, 2020, revised: October 14, 2020, accepted: November 12, 2020, Published: December 5, 2020.

${ }^{1}$ Heny Batara Maya is a Candidate Doctor in Criminology, Criminology, Social and Political Sciences, University of Indonesia, Depok, Indonesia

${ }^{2}$ Mohammad Kemal Dermawan is a Doctor in Criminology, Associate Professor, Criminology Social and Political Sciences, University of Indonesia, Depok, Indonesia.

${ }^{3}$ Vinita Susanti is a Doctor in Criminology, Associate Professor, Criminology Social and Political Sciences, University of Indonesia, Depok, Indonesia.

*Corresponding author: tianmarito189@gmail.com 
Heny Batara Maya, Mohammad Kemal Dermawan, Vinita Susanti

\section{Model Pencegahan Terpadu Kejahatan Penyelundupan Ganja di Wilayah Perbatasan Darat Indonesia-Papua-Nugini (Kasus: Distrik Muara Tami, Kota Jayapura, Provinsi Papua) \\ Abstrak}

Tulisan ini menjelaskan tentang perlunya suatu model pencegahan yang berdaya guna dalam mencegah penyelundupan ganja di wilayah perbatasan darat Indonesia-Papua Nugini di Distrik Muara Tami, Jayapura Papua. Model yang diterapkan selama ini, yaitu model outward looking, yang menerapkan pemeriksaan, pengawasan dan keamanan lintas batas secara terpadu. Pada kenyataannya, penyalahgunaan ganja yang berasal dari Papua Nugini masih mengkhawatirkan di wilayah perbatasan. Dengan pendekatan wawancara tidak terstruktur dan metode Delphi diperoleh data akurat bahwa model yang dilakukan sekarang dalam pelaksanaannya masih belum terlihat professional dan terpadu antara petugas pelayanan lintas batas, petugas keamanan (Polisi) dan pertahanan (TNI), Ondoaffi (tokoh adat), tokoh agama dan masyarakat perbatasan di wilayah Indonesia-Papua Nugini. Selanjutnya, masih lemahnya keterpaduan antara Kementerian/Lembaga terkait program dan anggaran dalam rangka pencegahan penyelundupan ganja di wilayah perbatasan Indonesia-Papua Nugini di Distrik Muara Tami, Kota Jayapura Provinsi Papua. Masih adanya orang-orang memilih melakukan penyelundupan ganja karena tidak merasa bersalah dan merupakan pekerjaan yang menguntungkan, jaringan sosial yang kuat, terdapatnya perilaku yang menetralkan dirinya bahwa membawa ganja bukan suatu kejahatan. Serta persoalan yang masih belum serius diantisipasi seperti persoalan geografis, demografis dan gangguan dari kelompok kejahatan bersenjata (OPM). Terkait persoalan tersebut, disertasi ini akan memberikan suatu langkah strategis, dengan beberapa rekomendasi kebijakan yang menguatkan model ini bisa memaksimalkan dan berdaya guna dari model sebelumnya.

Kata Kunci: Wilayah Perbatasan Darat, Kejahatan Terorganisir, Jaringan sosial, Netralisasi dan Metode Delphi, Model Pencegahan Kejahatan Penyelundupan Ganja

\section{Модель интергрированного предотвращения контрабанды марихуаны в сухопутной приграничной территории Индонезии-Папуа-Новой Гвинеи (Случай: район Муара Тами, город Джаяпура, провинция Папуа) \\ Аннотация}

В этой статье описывается потребность в эффективной превентивной модели предотвращения контрабанды марихуаны в сухопутной приграничной территории ИндонезииПапуа-Новой Гвинеи в районе Муара Тами, Джаяпура, Папуа. Применяемая до сих пор модель - это модель внешнего наблюдения, которая реализует интегрированный трансграничный контроль, надзор и безопасность. . Фактически злоупотребление марихуаной из Папуа-Новой Гвинеи по-прежнему вызывает беспокойство в приграничных территориях. С помощью подхода неструктурированного интервью и метода Дельфи получены точные данные о том, что текущая модель в ее реализации все еще не выглядит профессиональной и интегрированной между офицерами трансграничной службы, офицерами безопасности (полиция) и обороны (TNI), Ондоафи (традиционные лидеры), религиозными лидерами и приграничной общиной в территории Индонезия-Папуа-Новая Гвинея. Кроме того, все еще существует слабая интеграция между министерствами/ведомствами, имеющими отношение к программам и бюджетам, с целью предотвращения контрабанды марихуаны в приграничной территории Индонезии-Папуа-Новой Гвинеи в районе Муара Тами города Джаяпура, провинция Папуа. Некоторые люди по-прежнему предпочитают провозить марихуану контрабандой, потому что они не чувствуют себя виноватыми, и это прибыльная работа с сильной социальной организацией; они считают, что ношение марихуаны не является преступлением. Такие проблемы, как географические, демографические и вмешательство вооруженных преступных группировок (ОРМ), которые еще ждут своего решения, также являются факторами, способствующими этому преступлению. Основываясь на этом, данная статья даёт стратегический шаг с несколькими рекомендациями по политике, которые смогут максимально укрепить эту модель и сделать её более эффективной по сравнению с предыдущей моделью.

Ключевые Слова: Сухопутная Приграничная Территория, Организованная Преступность, Социальные Сети, Нейтрализация И Метод Дельфи, Модель Предупреждения Контрабанды Марихуаны. 


\section{A. INTRODUCTION}

Drugs have tremendous destructive power where their spread is increasing into Indonesian territory by being smuggled through the border areas (Joko Widodo, 2015). Drug smuggling is an anti-social detriment to society (Dermawan, M. Kemal, 2018) and poses a significant threat to national security, and has the potential to overthrow a country (Willem and Abraham, 2005; Perkins, 2010; Pushpita, 2016).

The problem in the land border area in Indonesia, which borders 3 countries, namely Malaysia, Timor Leste, and Papua New Guinea, is very complex. These problems are not only related to national borders but also issues of cross-border and border development. The land border between Indonesia and Papua New Guinea is one of the land border areas where the smuggling of marijuana drugs is still rife. Marijuana is smuggled through routes along the border in the Muara Tami District. Several cases of marijuana smuggling occurred in 2014 where the smuggled marijuana weighed $7.2 \mathrm{~kg}$ and was carried by Papua New Guinea residents, in 2015 there was a similar case with a weight of $4 \mathrm{~kg}$ of marijuana and was carried by a resident of Skouw, in $20161 \mathrm{~kg}$ of marijuana brought by Papua New Guinea residents and in 2017m, the smuggling of marijuana weighing 500 grams took place where the courier was a young man from Mosso Village. In 2018, 3 (three) $\mathrm{kg}$ of marijuana was also smuggled and brought by Koya Timur Muara Tami residents, while in 2019, a Papua New Guinea foreigner brought $1 \mathrm{~kg}$ of marijuana to the Skouw Border market in Muara Tami District.

Until the end of July 2019, data from the Jayapura City Police Drug Research Unit had revealed 39 cases with 47 suspected drug traffickers. This means that marijuana circulating in the city of Jayapura is a type of drug that has a high demand according to The Resort Police Chief of Jayapura AKBP Victor Dean Makboen. This is very reasonable considering that Jayapura City is the largest city (provincial capital) in Papua Province with a fairly rapid population growth dynamic where the population of Jayapura City is dominated by population groups aged 20-34 years(LintasPapua.com, 2018). This problem is proven through data that confirms that dealers are also marijuana users. The perpetrators came from various backgrounds, such as the case of an 11-year-old student who was caught for bringing marijuana through illegal channels near PLBN Skouw (2017) and another case in which the illegal passer/transporter (AT) is a perpetrator who has been jailed with a case the same (recidivist).

In this regard, although the border is marked or visible because of physical boundaries, such as the land border area of Indonesia-Papua New 
Guinea which has a national border in the form of a Meredian Monument, invisibility, for example, illegal flows or smuggling, cannot be predicted (Willem 2005). , such as the case of marijuana smuggling in the border area of IndonesiaPapua New Guinea in the Muara Tami District where officers cannot predict the presence of illegal passers/transporters (Djohan, 1996; Willem, 2005), through which route and when. From Endang Rudiatin's research (2012) it is known that the transaction process at the border is "unique", where the incident is difficult to distinguish, whether the trade is legal or illegal. Suko Bandiyono's (2004) research also reveals that it is difficult to see whether a passer is legal or illegal. This happens because in general they often go in and out of social events such as marriage, death, or religion. The people of the Indonesia-Papua New Guinea border have intense interactions with Papua New Guinea people who live around the border because they still have the same kinship and customs.

Regarding smugglers or illegal passers, that they are imaginary, it is difficult to reveal (Willem 2005). They do jobs that can change and increase the cost of living, meaning promising jobs (Salt, 2000; Liempt, 2007; Siegel, 2011; Pushpita, 2016; Hanafiah, 2018). These jobs are promising in terms of people who are in the middle of a weak economic situation or get profit to pursue pleasure (Bentham and Beccaria, 1963; Meier, 1989). This is further like in Endang's research (2012) which states that socio-economic and political conditions can open up opportunities in opening up socio-cultural resources to develop economic interests, meaning that social conditions affect creating space for other interests. It is strengthened that conditions in the border region between Indonesia and Papua New Guinea, especially in the Muara Tami District, need more attention because the government's role in supervising the area is not yet optimal, as well as the role of its citizens who are "passive" due to limited human resources. The connection between education and smuggling in the IndonesiaPapua New Guinea border region is that with a small number of teachers, it will have an impact on the low human resources of border communities, plus problems related to access to schools, including school infrastructure (Kusuma, Sihole and Saptono, 2017).

\section{B. METHODS}

The approach used in this research was a qualitative approach which aimed to obtain data on an integrated crime prevention model that can touch on the characteristics and conditions based on profit, organized crime, social ties, a justification for deviant behavior, geography, demographics, and conditions of interference from Armed Crime Groups (OPM). 
The location where the research was conducted is the border area of Indonesia-Papua New Guinea, precisely in Muara Tami District, which is a district directly adjacent to Papua New Guinea, to be precise the Wutung District, Vanimo, Papua New Guinea. This region has a population of 12,626 spread over 2 urban villages and 6 villages with an area of $626.7 \mathrm{~km}^{2}$. Besides, this district is also the largest in Jayapura City(Central Bureau of Statistics Jayapura City, 2018). The largest population in Muara Tami district is 0-4 years old, totaling 1,532 people, 5-9 years old as many as 1,329 people, and ages $25-29$ years totaling 1,363 people. The village directly opposite the Kampung Wutung (PNG) is the Mosso village which has 486 inhabitants.

To obtain accurate and in-depth data regarding the prevention of marijuana smuggling, the method was carried out in 2 (two) stages, namely unstructured interviews and the Delphi method. The unstructured interview aims to deepen data related to the failure of the marijuana smuggling prevention model and is related to data that can help researchers to find an integrated marijuana smuggling prevention model that can address the characteristics and conditions that can strengthen and support the crim (Sources of Data: Institution related to the border, Security/Defence, Public Figures of Custom/Religion, The Community, NGO, Practitioners, and Academician).

The results of unstructured interviews that have not been resolved became an issue for the Delphi method, where the issue was consulted with experts as a resource that researchers choose based on their competence or expertise so that the issues raised could be answered. The Delphi method in this study was carried out in 2 (two) rounds with the same resource person. Round I aims to obtain input on the issue of marijuana smuggling in the land border area of Indonesia-Papua New Guinea in Muara Tami District. Round II aims to solve the marijuana smuggling issue obtained from the Delphi I round results so that in the second round, and accurate and accountable or adequate consensus answer can be obtained. In this second round, the unsolved issues were continued by the researcher to be analyzed separately.

\section{RESULTS AND DISCUSSION}

\section{Analysis of recent research and publications}

In creating a model for preventing the crime of marijuana smuggling in the land border area of Muara Tami Papua District, the author used the Delphi methodology which began with unstructured interviews with competent sources who can answer questions so that the researcher can reach the target data. The 
issues included in Delphi II were differences that originate from the results of Delphi I. These issues are as follows:

- Infrastructure facilities that have not been maximal in assisting officers to inspect, supervise and secure border crossers of people and goods, especially on traditional routes that have not been detected $\bullet$ Employment through tourism, management of idle land, and increased trade in natural products have not been maximized and managed properly. The community has not maximally taken advantage of traditional/local market opportunities (trade-in garden products, tourism potential, or new businesses).

- Kinship or in the same environment supports them directly or indirectly, such as not reporting or not reacting when they see residents around them being involved in the crime of marijuana smuggling. The history of disappointment with defense and security institutions is still strong and separatists are mingling with society.

- The weakening of cultural norms and values of border communities where the role of Ondoaffi, religious and community leaders has not been optimal. Besides, the relationship between the government and border communities is still low, especially the relationship between regional and provincial governments.

- Law enforcement and deterrent effects are not maximally carried out, both for smugglers and officers who commit violence/violate the law, including the lack of efforts to educate citizens about the rules of marijuana abuse and the dangers of using marijuana.

By using the Delphi interview guide (Delphi Round I), these issues were re-consulted with the same resource persons and the results were that there were still differences in implementing border development policies where the parties concerned were still doing it individually or prioritizing the sectoral ego $\mathrm{K} / \mathrm{L}$ in Supervision, Mapping/Data Collection, Inspection, and Security, as well as Human Resource/Natural Resources Management and Planning and Budgeting of Marijuana Smuggling Prevention Activities.

\section{Main Part}

From the Delphi round II method, it was found that in carrying out activities in the land border area, the 27 Ministries and Institutions were based on the rules made, or each $\mathrm{K} / \mathrm{L}$ has its authority in carrying out its duties in 
budgeting activities and is based on the rules/SOP for activities in the region borders without prior coordination, without sharing data and information related to traditional routes.

In the process of making the model, the differences are shown by the results obtained from Delphi round II, which can be called obstacles. These obstacles were then included in the Delphi process which was confirmed over and over again with the same sources, in this case, practitioners/academics, where the results obtained were subsequently made an important issue in Delphi II. The obstacles/differences that are meant by crime experts will not maximize crime prevention to reduce crime rates and as a form of crime prevention.

\section{DELPHI PROCESS OF THE INTEGRATED PREVENTION MODEL FOR MARIJUANA SMUGGLING IN LAND BORDER REGION OF INDONESIA-PAPUA NUGINI (CASE: MUARA TAMI DISTRICT, JAYAPURA CITY, PAPUA PROVINCE)}

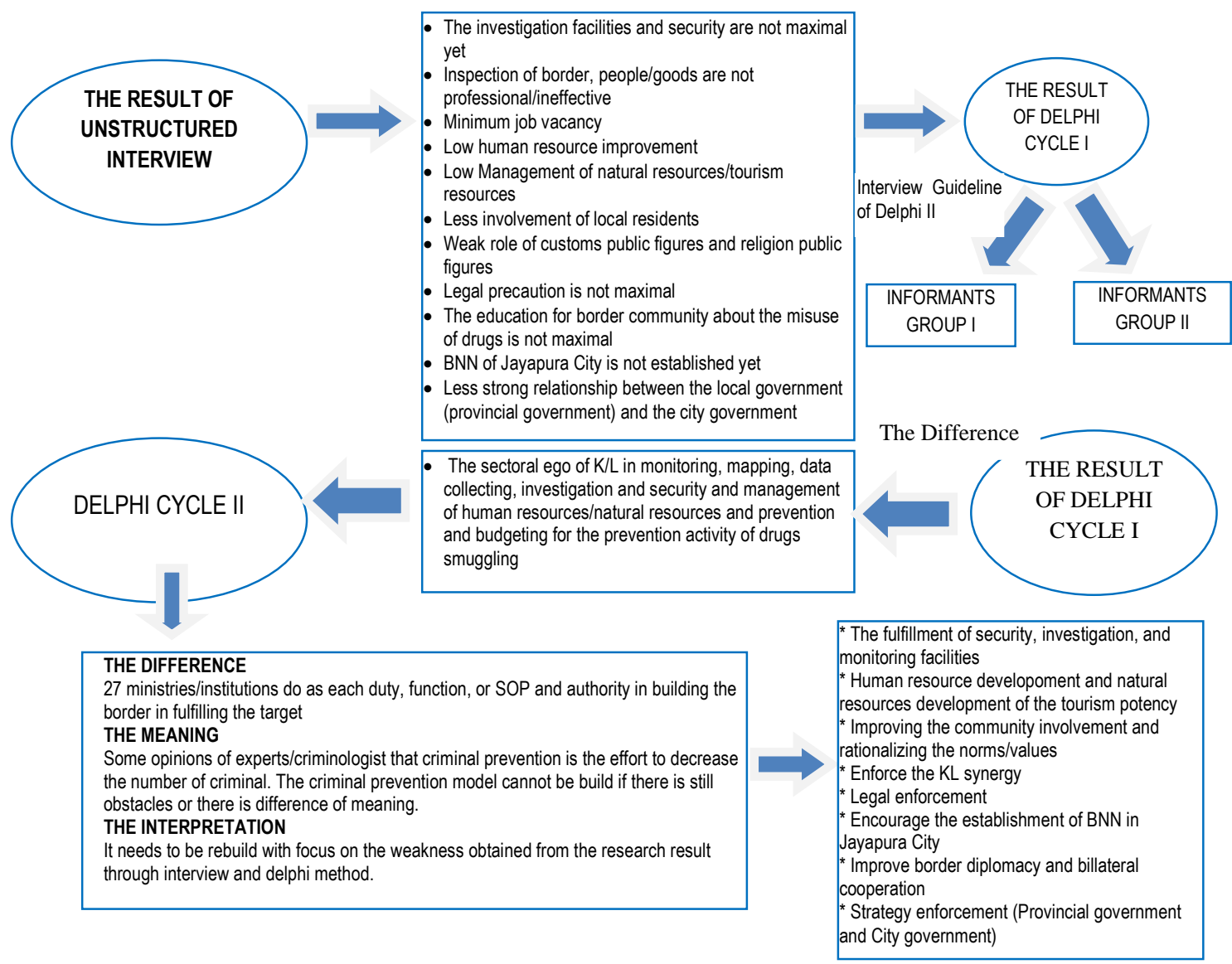


The crime prevention model cannot be designed if there are still obstacles or differences. This difference means that sectoral egos in terms of border management that can prevent the crime of marijuana smuggling can be carried out through efforts or strategies that can integrate programs/activities where these efforts can be used to formulate models, along with SOPs for border management. Opinion Selmini (2010) explains that prevention emphasizes efforts to produce integrated crime prevention, through coordination or synergy which is important to do in increasing effectiveness, efficiency, and productivity to achieve optimal goals. Without good synergy or coordination in preventing smuggling, it will be difficult to achieve the goals that all elements, both government and non-government and border communities want to achieve. Maximum synergy or coordination is needed so that the achievement of goals can run more smoothly, effectively, and efficiently than before.

The crime prevention model cannot be designed if there are still obstacles or differences. This difference means that sectoral egos in terms of border management that can prevent the crime of marijuana smuggling can be carried out through efforts or strategies that can integrate programs/activities where these efforts can be used to formulate models, along with SOPs for border management. Opinion Selmini (2010) explains that prevention emphasizes efforts to produce integrated crime prevention, through coordination or synergy which is important to do in increasing effectiveness, efficiency, and productivity to achieve optimal goals. Without good synergy or coordination in preventing smuggling, it will be difficult to achieve the goals that all elements, both government and non-government and border communities want to achieve. Maximum synergy or coordination is needed so that the achievement of goals can run more smoothly, effectively, and efficiently than before.

The outward-looking model is an integrated model that is expected to prevent marijuana smuggling. In its implementation, this model experiences many challenges and obstacles so that smuggling which is predicted to be eradicated, in fact still occurs, even the users are increasing and it is more worrying where the users are also students. Through the use of an integrated model, coordination can be maximized due to follow-up. The follow-up is a real action that is expected to give rise to the belief that the government is serious about making Muara Tami and its people live in prosperity and security.

As stated by Heal (1992), the combination of ideas from the parties from the policymakers, academics, and the practice can produce a maximum prevention model. This combination of ideas can answer the question related what kind of an integrated model of prevention of the crime of marijuana 
smuggling which can touch the characteristics and conditions based on rational choice, organized crime, established social relations, and the justification of perpetrators for crimes committed in Indonesia's land border areas and Papua New Guinea in the Muara Tami District of Jayapura. The theoretical approach related to this among others is explained by Salt (2000) and Liempt (2007) which touches on the characteristics that the smuggling of marijuana is an organized crime as a result of the perpetrator's rational judgment in considering the advantages and risks of being caught by the minor (Larry J. Siegel and Coleman's view), 2011). Besides, in this theory, it is also explained that the characteristics of social / kinship networks can act as reinforcements or ties that facilitate and support the crime of smuggling marijuana in the Indonesia-Papua New Guinea border area, and touch the characteristics of neutralization as an attempt by the perpetrator to strengthen his innocence/justification by the perpetrator in strengthening the motive for smuggling marijuana in the border region of Indonesia-Papua New Guinea (Sykes and Matza, 1957).

\section{CONCLUSIONS}

The design of an integrated crime prevention model in dealing with marijuana smuggling in the Indonesia-Papua New Guinea Border region in the Muara Tami District is feasible. This is in line with the results of interviews with resource persons from government circles, experts/practitioners, NGOs, border residents, traditional and religious leaders. The purpose of designing an integrated model is because the existing model has not been able to function optimally so that the designed model can increase knowledge to deal with gaps, potentials, and challenges faced and it is predicted to be more dynamic. Through maximum synergy and coordination, cross-border barriers and problems will be unraveled, including inspection and supervision of traditional routes, as well as a new model designed to be a breakthrough or impetus for ministries that have policies in the land border area of Indonesia-Papua New Guinea in Muara District. Tami is more serious in programming activities so that all related parties can be integrated, to produce an effective and efficient Out Put in preventing the crime of marijuana smuggling.

This journal presents an integrated crime prevention model and reconstructs the old model contained policies that can address all existing problems. Information regarding these problems is the result obtained from observations, research, interviews, and the results of the Delphi I and 2 method processes. As for the integrated process, this journal discusses the development or fulfillment of infrastructure/support/samples / data; land border supervision, 
security and services; development of human resources in border communities and management of tourism potential as well as increasing commodities; increasing the participation of border communities in rationalizing cultural norms and values as a deterrent to deviant behavior; strengthening Ministries and Institutions in the prevention of marijuana smuggling crimes, legal protection for border checks, security, surveillance, and border services; and enhancing border diplomacy and bilateral cooperation.

\section{REFERENCES :}

Abadinsky, H. 1990. Organized Crime-Third Edition. Nelson-Hall Chicago.

Agustin, H. 2003. Studi Literatur Jaringan Sosial.

Alexander, et, al. "Borderlines and Borderlands Political Oddities at the Edge of NationState."

Ardhana, G.I.B. 2007. Perspektif baru Keamanan Nasional, Pusat Penerangan TNI, 02 Juli.

Arendt, H. 1993, Asal-usul Totaliterisme, terj. A. Agus Nugroho, Yayasan Obor Indonesia, Jakarta.

Arjawa, GBP. Suka. 2014. Pilihan Rasional di balik Pembebasan Corby. FISIP Udaya. Vol. 8. No. 1/2014-09 TOC: 4, and page : $49-62$.

Asiwaju. 1983. Borderlands Research: A Comparative Perspective. El Paso: University of Texas (Border Perspectives Paper) Center for Inter American and Border Studies, University of Texas.

Astari, W. 2017. “Kebijakan Pemerintah Indonesia Dalam Mengantisipasi Perkembangan Gerakan Terorisme Dikawasan Asia Tenggara Tahun 2010-2015" Jurnal Hubungan Internasional.Vol 4 No. 2 Oktober.

Badan Pusat Statistik Kota Jayapura. Distrik Muara Tami Dalam Angka 2018.

Baird, Theodore. 2013. Theoretical approaches to Human Smuggling. DIIS Working Paper.

Barack, G . 2002. "Integrative Theories". Encyclopedia of Crime and Punishment Ed. David Levinson. Sage.

Barlow, D.H. 1995. Crime and Public policy: Putting Theory to Work, Boulder: Westview Press. 
Bentham, J. 1960. Introduction to the Principles of Morals and Legislation. Oxford: Basil Blackwell.

Block, RL; \& Block, CR. 1994. Space, Place, and Crime: Hot Spot Areas and Hot places of Liquor-Related Crime.

Boissevain, J.F. 1974. Friends of Friends. Networks, manipulators, and Coalitions. Oxford: Blackwell.

Buzan, B. et.al. 1998. Security A New Frame Work for Analysis. London: Lynne Rinner Publishers.

Carlos, J.V. 2009. The Spatial Dynamics and Socioeconomic Correlates of Drugs Arrests in Mexico City

Chilenski, 2010. The Macro to the Micro: A geographic Examination of the Community Context and Early Adolescent Problem Behaviors.

Clad, J. 2011. Delineation and Borders in Southeast Asia. Dalam Jame Clad dan Sean M. Mc. Donald (ed). The Borderlands of Southeast Asia: Geopolitics, Terrorism, and Globalization. NGU Press.

Clarke, RV. 1983. Situational Crime Prevention: Its Theoretical Basis and Practical Scope. Journal of Crime and Justice, Vol. 4. The University of Chicago Press.

Clinard, M.B; \& Quinney, R. 1972. Criminal Behaviour Systems. A Typology. Edition 2. New York: Holt, Rinehart, and Winston, Inc.

Cohen, A. 1955. Delinquent Boys: The Culture of the Gang. Glencoe, IL: Free Press.

Coleman, J. 2011. Dasar-dasar Teori Sosial (Foundation of Social Theory). Translated by. Uttaqien L. Widowati, Purwandai. Bandung: Nusa Medai.

Crawley, D; Jones et.al. 2018. Unravelling Europe's Migration Crisis. Policy Press Shorts Insights.

Cuhls, Kerstin. 2018. "Delphi Method" United Nations Industrial development organizations. Diakses melalui http://www.unido.org/fileadmin/import/16959 DelphiMetod.pdf, pada Juli 2018.

Dermawan, M.K. 2001. Pencegahan Kejahatan: Dari Sebab-sebab Kejahatan Menuju Pada Konteks Kejahatan. Jurnal Kriminologi Indonesia, Vol. I, No. III , 35

Dermawan. 2000. Teori Kriminologi. Edisi 2. Penerbit Universitas Terbuka. 2000 
Edwards, A \& Gill, P. (Eds.). 2004. Transnational Organised Crime: Perspectives on Global Activity New York: Routledge.

Fahmi. Kerentanan indonesia dari ancaman kejahatan terorganisasi (organized crime) pada sektor-sektor ekonomi, kemananan hingga politik. Jurnal Sosiologi, Vol. 16, No. 1: 46-51

Finckenauer, J. 2000. Meeting the Challenge of Transnational Crime. National Institute of Justice Journal, July.

Giay, B. Menuju Papua Baru (beberapa pokok pikiran sekitar emansipasi orang Papua). Deiyai, Jayapura.

Giddens, A. 1985, The Nation-State And Violence, Cambridge: Polity Press.

Gilling, D. 1997. Crime Prevention. Theory, Policy, and Politics. London: University College London (UCL).

Ginong, M. 2016. Identias Kolektif Amerika Serikat dan Meksiko dalam Merida Initiative 2008 untuk menanggulangi Peredaran gelap Narkotika (Periode 2008-2014). Journal of International Relations, Volume 2, Nomor 1, Tahun 2016, hal. 67-78

Granovetter, M. 1985. "Economic Action and Social Structure: the Problem of Embededdedness" dalam American Journal of Sociology, Vol. 91, Edisi 3.

Gutierez, EG. 2010, "Security, Drugs, and Violence in Mexico: A Survey", (Mexico City: Foro De America Del Norte.

Haba, John. 2017. Beta Orang Kupang. Yayasan Pustaka Obor Indonesia.

Handoyo, P. \& Ingrid. 2016. 40 Tahun perang Melawan Narkotika: Pengelolaan Narkotika oleh negara, perang bukan solusi. Jurnal Peradilan Indonesia. Vol. 5 Agustus 2016. - Januari 2017.

Hawkins, K. 1992. The Use of Legal Discretion: Perspective from Law and Social Science", The Use of Discretion, ed. Keith Hawkins, (New York: Oxford University Press Inc.

Heal, K. 1992. Changing Perspectives on Crime Prevention: The Role of Information and Structure. Crime, Policing, and Place: Essays in environmental criminology. Ed. David Evans J. et al., London: Routledge.

Henry, S; \& Milovanovich, D. 1996. Constitutive Criminology. Beyond Postmodernism. London: Sage Publications. 
Intan, P; \& Wiwik dkk. 2014. Peran Amerika Serikat dalam Kerjasama Penanggulangan Perdagangan narkotika di Meksiko 2007-2012.

Iskandar, Z. 2008. Bung Hatta Pernah Menangis Melihat Kondisi Perbatasan. Antara news, Save Our Borneo, Wednesday, 03 September.

Jailly, EB. 2012. A Companion to Border Studies: Securing Borders in Europe and North America (UK: Blackwell Publishing Ltd.

Jakub J.Grygiel. 2006." Greats Powers and Geopolitical Change (Maryland.The Johns Hopkins University Press.

Kusnadi. 1998. Jaringan Sosial Sebagai Strategi Adaptasi masyarakat Nelayan. Studi Kasus di Desa Pesisir, Kecamatan Besuki. Kabupaten Situbondo, Jawa Timur. Tesis Antropologi. Depok: Program Kerjasama FISIP UI.

Laremont, RR., 2005. Borders, Nationalism, and the African State. London: Lynne Reiner.

Leiner, M.M; and Stuart Henry. 2004. Essential Criminology. Colorado: Westview Press.

Maisini, A. 2015. Pelayanan Publik oleh Pemerintah Daerah dalam Penyelenggaraan Otonomi Khusus Papua. Lex Administratum.Vol.III/No.4/Juni.

Mansoben, J.R. 1995. Sistem Politik Tradisional di Irian Jaya. Leiden: LIPI-RIJKS Universiteit Leiden.

Marwasta, D. 2016. Pendampingan Pengelolaan Wilayah Perbatasan di Indonesia: Lesson Learned dari KKN-PPM UGM di Kawasan Perbatasan. Indonesia Journal of Community Engagement. Vo. 01, No.02, Maret.

Marwasta, D. 2016. Pendampingan pengelolaan wilayah perbatasan di indonesia: lesson learned dari kkn-ppm ugm di kawasan perbatasan. Indonesian Journal of Community Engagement Vol. 01, No. 02, Maret.

Mastrobuoni, G; \& Patchini, E. 2010. Understanding Organized Crime Networking: Evidence-Based on Federal Bureau of Narcotics Secret Files on America Mafia.

Matthew B.C. 2013. Drug Trafficking Related Violance and Corruption Among Specific Populations in Mexico. Eastern Kentucky University, Encompass.

Matuan, M. 2013. Efektivitas penyelenggaraan pemerintahan kampung di distrik silimo kabupaten yahukimo provinsi Papua.

Media Keuangan, 2017. Melindungi Negara dari narkoba. Volume XIII/No.127/April 2018 
Meier, Robert F. 1989. Crime and Society, Boston: Allyn and Bacon.

Moraczewska, A. 2010. "The Changing Interpretation of Border Functions in International Relations", Revista Románá de Geografie Politicá, Year XII, No. 2, November.

Mustafa, M. 2001. Kriminologi. Kajian Sosiologi Terhadap Kriminalitas, Perilaku Menyimpang dan Pelanggaran Hukum. Bekasi: sari Ilmu Pratama (SIP).

Mustafa, M. 2005. Metodelogi Penelitian Kriminologi; Fisip UI Press Depok.

Nainggolan, P. 2011. Kepentingan pemerintah uruguay melegalisasi ganja pada masa pemerintahan Jose Alberto Mujica Cordano tahun 2010-2015. JOM FISIP Volume 2 No.2 Oktober 2015

Nikolas. 2014. Penyalahgunaan Pas Lintas Batas oleh Pihak Ketiga Terhadap Terjadinya Kejahatan Melalui Pos Lintas Batas Jagoi Babang.Tesis.

Passas, N. 2003. Cross border crime and the interface between legal and illegal actors' Security Journal, Vol. 16 (1).

Paternoster, R. 1989. Decisions to participate in and desist from four types of common delinquency: Deterrence and the rational choice perspective. Law \& Society Review, 23(1), 7-40.

Payan, T. 2006. 'The Three US - Mexico Borders Wars", (London: Praeger Security International.

Payan, T. 2006. The Three US - Mexico Borders Wars, (London: Praeger Security International.

Peredaran Ganja, Papua Berstatus Waspada". Diakses dari http://kabarpapua.co/peredaran-ganja- $\quad$ papuaberstatus-waspada/, pada tanggal 7 Juli 2018.

Polk, K. 1998. Putting Theory into Practice. The criminology Department University of Melbourne.

Prescott, V; \& Gillian D. Triggs. 2008. International Frontiers and Boundaries: Law, Politics and Geography, Boston: Martinus Nijhoff Publishers.

Putra, P; Adhimukti. 2016. Evaluasi kerjasama unodc dan pemerintah indonesia dalam mengatasi perdagangan narkoba jenis crystalline methamphetamine di indonesia (2007-2013), Journal of International Relations, Volume 2, Nomor 2, Tahun 2016. 
Putri, D; \& Blickman, T. 2016. Ganja di Indonesia, Pola Konsumsi, Produksi dan Kebijakan. Drug Policy Briefing. Vol. 44. Januari.

Putri, D; \& Blickman, T. 2016. Ganja di Indonesia. Pola Konsumsi, Produksi, dan Kebijakan. Drug Policy Briefing, Vol.44. Januari.

Ramanda \& Aqil, 2017. Indonesia President Joko Widodo and The Philippines President Rodrigo Duterte's Approaches towards the war on drugs: A Comparative Analysis. APSPA Book Series. Hal. 119-141

Reksodiputro, M. 1997. Bunga Rampai Permasalahan dalam Sistem Peradilan Pidana: Faktor-faktor yang mempengaruhi terjadinya kejahatan terorganinasi di Indonesia (suatu Tanggapan). Penerbit Pusat Pelayanan Keadilan dan Pengadilan Hukum UI, Edisis pertama. Cetakan Pertama, Jakarta.

Rudiatin, E. 2012. Integrasi Ekonomi Lokal di Perbatasan. Departemen Antropologi, FISIP UI.

Salt, J. (Ed.). 2000. Perspectives on Trafficking of Migrants. Geneva: International Organization for Migration (IOM).

Salt, J. 2000. Trafficking and human smuggling: A European perspective. International Migration, 38(3).

Schendel, WV. 2005. Illicit Flows and Criminal Things. Indiana University Press.

Schultz, P.W. Nolan, Cialdini, Godstein. 2013. The Constructive, Destructive and Reconstructive Power of Social Norms. New York.

Scraton, P. 2007, Power, Conflict, and Criminalisation. Oxxon Routledge

Shirk, D. Trannational Crime, US Border Security and the War on Drug inMexico.

Siegel, JT. 2000. The Rope of God, Ann Arbror: University of Michigan Press.

Siegel, L. 2000. Criminology. Edition 7, Stamford: Wardsworth.

Silalahi, TSA. 2000. Penyalahgunaan Narkoba di Kalangan Remaja: suatu perspektif. Jurnal Kriminologi Indonesia Vol. 1 No. I September.

Slama, M. 2011. 'Translocal Networks and Globalisation within Indonesia: Exploring the Hadhrami Diaspora from the Archipelago's North-East'. Asian Journal of Social Science 39(3): 238 - 257.

Smith, D. 2007. The Mafia Mystiques. 2007.

Sykes, G.M. 1957. Techniques of Netralization: A Theory of Deliquency, Irvington Pub. 
The War on Drugs, HIV/AIDS, and Violations of Human Rights in Thailand," Human Rights Watch, http://www.hrw.org/legacy/campaigns/aids/2004/thai.htm (21 Agustus 2018)

Timisela, SG. 2015. Dampak Perdagangan Lintas Batas Terhadap Perekonomian Masyarakat Lokal (Studi Kasus: Wilayah Perbatasan RI-PNG di Distrik Muara Tami). JESP-Vol.7, No. 2 Nopember 2015.

Tippe, S. Relasi Sipil-Militer dalam Pemberdayaan Masyarakat Papua. Jurnal Sosiologi Masyarakat, Vol.19, Juli 2-14.hal.287-303

Trijono, L. 2006, "Otonomi Khusus dan Pembangunan Aras Lokal Papua", dalam Analisis CSIS, Vol. 35 No. 4 Desember.

W. Jhon, Creswll. Research Design, alih Bahasa oleh angkatan III dan IV

Widodo, 2006,' Analisis Kriminologis tentang Penyebab Pelakuk kejahatan Ynag Berhubungan dengan Komputer (Studi di Unit Infotek/CYBERCRIME, Mabes Pol RI)

Wolfgang, M. E. et.al., 1970. The Sociology Of Crime and Delinquency. New York: John Wiley \& Sois. Inc

Yudha \& Ibnu, 2017, Indonesian President Joko Widodo and the Philippines President Rodrigo Duterte's approaches towards the war on drugs: a comparative analysis. APSPA Book Series Social and Political Issues in Asia: In The Context of Global Changes, Edition 2017.

Zabyelina, Y. 2009. Unpacking Pandoras's Box: Defining Transnasional Crime and Outline Emerging Criminal Trends". Central Europe Journal of International and Security Studies, Vol. 3 May.

Zhao DKK. 2011. A System's Approach to Crime Prevention: The case of Macao. Asian Criminology 6. (2011). 